\title{
The fragmented route to a whole institution approach to integrating learning development. Reporting on a work in progress
}

\author{
Dr Frances M Gibson \\ St George's University of London, UK \\ Janette Myers \\ St George's University of London, UK
}

\begin{abstract}
This case study outlines a route to developing institutional approaches to learning development, in particular to the introduction of integrated learning development. There are two key messages. One is the role of isolated examples of change in practice in producing wider institutional and attitudinal change. The other is the nature of the interaction between learning developer and academic in creating opportunities for integration. One initiative within the overall project is explained in detail to give a flavour of the project and to explain the role of individual initiatives in creating opportunities for learning development and in contributing to a process of change.
\end{abstract}

Keywords: collaborative learning development; integrated learning; institutional change.

\section{Why integrate learning development?}

The underpinning rationale behind integrating learning development is that as well as learning about a body of knowledge, students should also become involved in understanding how knowledge is constructed through practice, enhancing their development as students (Warren, 2002). This links to approaches such as academic literacies and academic socialisation in its view that knowledge and skills are subject based and develop in the context of interaction between student, subject teacher and discipline (Lea, 2004). This view also has important pragmatic consequences. If this kind 
of learning opportunity forms part of timetabled activity then it is more likely to reach a wider group of students. Wingate (2007) argues that extra curricular learning development suffers from limitations because it addresses the needs of only a few students and is usually offered after a problem has developed. To benefit from it students have to accept that they need it and make the effort to attend. This has particular implications at an institution such as St George's University of London (SGUL) where many of our students have high attainment and are used to being high achievers. Support that appears to be addressing low achievement seems to them to be of no relevance. In addition, the difficulties that may lead some students to struggle may make it difficult for them to make time to attend separate sessions. Finally, this type of provision may also have the disadvantage of being stigmatising.

Integrating learning development with the curriculum reinforces many messages that we would like to send to students in other contexts. First, learning is a developmental process in which all students are engaged and which all students should find challenging at times (Earwaker, 1992). This can be a new and destabilising experience for some of our students. Second, professional healthcare workers should be assessing their abilities and addressing their learning needs at all stages in their career. Third, the institution has confidence in their ability to learn and to cope with their higher education and in its ability to enable students to learn. Although these messages have been developed in a health care education context they are of relevance to all students.

Developing an integrated approach can require a process of change in individual and institutional practice. Institutions vary in the extent to which learning developers can create top down change, for example, via direct input to teaching and learning strategies. Malcolm (2009) describes the University of Abertay's teaching and learning strategy which requires subject teachers to develop students as independent learners through their teaching and prescribes that active enquiry forms $60 \%$ of contact time. D'andrea and Gosling (2001) have identified best practice as a cross-institutional approach which links teaching teams, embeds innovative practice into departments and has direct reporting into institutional committees and structures. An alternative, or precursor, approach for the learning developer without access to institutional policy is to work in a more fragmented way, collaborating with individual lecturers to produce examples of integrated provision. This provides learning opportunities for students and may help to create an environment in which the fragments can be joined to create a whole institution policy. 


\section{The role of the subject lecturer in integrating academic and learning development}

This project is part of an approach which recognises academic colleagues' desire to see their students learning well and also acknowledges the considerable demands on colleagues' time. The complex range of factors operating in this area is reflected in the range of approaches taken to integration, leading to the fragmentation mentioned in the title of this paper. In our case a range of learning and teaching activities has been developed as opportunities have arisen, for example, when academic colleagues have suggested collaboration with learning development. Networking is important to identifying opportunities for collaboration and potential collaborators. Wingate (2006) argues that effective support can be provided via integrating learning development with subject teaching. We are working on this whilst also keeping our eye on the prize of a whole institution approach to the embedding of learning development within the curriculum.

Wingate has identified that university lecturers may be reluctant for a number of reasons to 'teach more than subject knowledge' (Wingate, 2007: 396). A number of factors contributing to this are identified. Lecturers may fear that this will leave little time for the curriculum and that it will draw on knowledge and skills they do not have. They also fear that the development of integrated teaching sessions will take up a lot of their time, further encroaching on research time. Lecturers' expectations of student preparedness may be both high and implicit, and can be based on beliefs about students' pre-university educational experience derived from their own sixth form days (Myers, 2007; Myers, 2008). The question of whether lecturers facilitate learning or deliver material is another issue. The ubiquitous use of the word deliver when the word teach might usefully be substituted could be argued to shape thinking about this issue, implying it is the job of the lecturer to transmit a body of information rather than to enable students to learn about their subject. Whilst this represents a polarised view of a division between those interested only in the transmission of subject knowledge and those with a wider interest in learning, it is helpful to acknowledge these anxieties so that they can be addressed. 


\section{The case study}

\section{The institutional context}

SGUL is a small College of the University of London specialising in healthcare subjects. The creation of a new post of Senior Lecturer in Student Learning and Support in 2008 presented the opportunity to think about the role of learning development. The challenge was to create a model of learning development that served all students, integrating learning development, teaching and the curriculum. For the reasons explained above the decision was taken to try to start this from the ground up, and follow initial activity with working to get the approach adopted as a formal part of teaching and learning strategy and embedded into curriculum design. This project arose out the new post holder's aim to integrate learning development, teaching and the curriculum. This case study refers to the initial, ground-up stage. The purpose of the work was to indentify existing and create new opportunities for students to develop academic skills as part of their usual subject learning.

SGUL has a mixture of selecting and recruiting courses and many of our undergraduate students have very high ' $A$ ' level points scores. Approximately half of our students are medical students, the other half study a range of healthcare and biomedical courses. Existing learning support at the College uses a range of models developed on a course by course basis to address the needs of specific students. These models vary in their level of integration; some are outside the curriculum, some relate but are taught separately, and some are fully integrated. Most are directed at preventing or addressing failure. At the $5^{\text {th }}$ LDHEN Symposium in 2008 Janette Myers suggested that these models could be likened, in our healthcare institution, to either a sticking plaster or a vaccination, designed to address or prevent problems. She invited the audience to suggest a metaphor for a more integrated and ongoing form of learning development, so thanks to the colleague who suggested a transdermal patch (e.g. a nicotine patch).

\section{The project aims}

We sought to extend our existing learning development provision, creating more examples of integrated practice with a developmental rather than a remedial focus. Our students have a lifelong responsibility to engage in continuous professional development, recognising and addressing their learning needs at all stages of their careers. This means that learning development can be seen as ongoing, not a once and for all preventive fix, and not just for students who are struggling academically. We also sought to question 
assumptions held by staff and students about the extent to which study at 'A' level, however successful, prepares students for studying at degree level and to ask whether we could assume that students would know how to study in the ways demanded by their courses. To address these issues the Senior Lecturer in Student Learning and Support (Janette Myers) sought to work with colleagues to develop ways of integrating learning development into individual teaching sessions and eventually into the curriculum. In order to do this she collaborated with interested individuals who would develop integrated teaching sessions, evaluate the process and provide their colleagues with information on how they carried out the task.

\section{Integrating learning development at St George's}

The approach that has been adopted is to encourage as wide a range of projects as possible under the umbrella of linking the encouragement of learning with subject teaching. Using Warren's typology, some projects are fully integrated, in that learning development is part of normal subject teaching, and some are semi integrated in that they are separate sessions linked to the curriculum (Warren, 2002). The central aim is for teaching staff to ask how they can use their subject teaching to help students to learn. This has resulted in a number of teaching sessions which together form the first stage of the process of institutional development. The next stage is to disseminate accounts of these individual projects to encourage the development of further sessions and to work towards the goal of integrating learning development with the curriculum. We are moving away from the sticking plaster for failure via the ongoing transdermal patch of continuous support to the oxygen of continuous development.

This section of the paper is an account of one project in the first stage of the programme. It describes the processes we went through to create, teach and evaluate the session. The two practitioners were Frances Gibson, a Senior Lecturer in the Division of Cellular and Molecular Medicine, and Janette Myers, a Senior Lecturer in Student Learning and Support. We met when Janette attended a problem based learning session which Frances facilitated and continued to meet at various university occasions. Frances is a very useful person in the institution because she bridges two large courses, the BSc in Biomedical Science and the 4-Year stream of the MBBS Medical Degree, having senior roles in each. At the time of the project she was also a student on the Postgraduate Certificate in 
Healthcare and Biomedical Education. This project also formed the basis for an assignment for the Certificate.

The students were second year Biomedical Science students who took part in a lecture on Flow Cytometry. There were 120 students in the group. Previously this subject has been taught via a didactic lecture. The learning development aim was to answer the question 'How can I help the students to learn during my lecture? This was to take place alongside the teaching about Flow Cytometry.

In order to begin the process of developing the session we discussed some of the issues involved in helping students to learn, focussing on the desired outcomes of the session, both in terms of subject knowledge and learning development. The aim was to help students learn during the lecture and to develop their ability to study the lecture material independently. We were concerned to indicate to students that whatever was done in this lecture could also be used in subsequent learning. We also considered the particular issues caused by the large lecture format. Janette reviewed some teaching techniques that had been used in similar situations and we decided to use the extended learning outcomes format developed by Janette Myers and Dr Ruth Kirk at Kingston University. Extended learning outcomes link the traditional list of learning outcomes (LOs) to ways in which students can develop and demonstrate their knowledge by explaining how the outcomes can be achieved. An example is given in Table 1. 
Table 1. Example of extended learning outcomes.

\begin{tabular}{|l|l|l|l|}
\hline $\begin{array}{l}\text { Learning } \\
\text { outcome }\end{array}$ & $\begin{array}{l}\text { When will I be } \\
\text { tested on this } \\
\text { learning } \\
\text { outcome? }\end{array}$ & $\begin{array}{l}\text { How should I } \\
\text { achieve this } \\
\text { learning outcome? }\end{array}$ & $\begin{array}{l}\text { You know that you } \\
\text { have achieved the } \\
\text { learning outcomes if } \\
\text { you can... }\end{array}$ \\
$\begin{array}{l}\text { 4. Discuss } \\
\text { staining of } \\
\text { surface and } \\
\text { cytoplasmic } \\
\text { antigens. }\end{array}$ & $\begin{array}{l}\text { In Semester 3 } \\
\text { exam and } \\
\text { synoptic exam }\end{array}$ & $\begin{array}{l}\text { During lecture, make } \\
\text { notes using learning } \\
\text { outcomes as } \\
\text { headings. }\end{array}$ & $\begin{array}{l}\text { List common sources of } \\
\text { cells for flow cytometry. }\end{array}$ \\
& & $\begin{array}{l}\text { nd } \\
\text { notes in handbooks. } \\
\text { Read Resources (1, } \\
\text { 3). Make notes using } \\
\text { learning outcomes as } \\
\text { headings. }\end{array}$ & $\begin{array}{l}\text { Describe and } \\
\text { differentiate between } \\
\text { direct and indirect } \\
\text { fluorescence labelling. }\end{array}$ \\
\hline
\end{tabular}

Study hints can be included such as reminding the students of material that has already been covered and showing how to relate new material to that already known. Additionally, reading resources, both subject and study related can be provided. An important feature is that extended LOs explain how the students would know when they have achieved the outcomes. This process is designed to scaffold student understanding of how they might use learning outcomes in self directed study so that eventually they can create extended learning outcomes for themselves.

Extended LOs were built into the lecture to focus students on the intended outcomes of the session and indicate to them how they could use the LOs to develop their learning of the subject material. The lecture was structured around seven LOs. A summary slide listing these seven sections was shown at the beginning and at the end of the lecture and after each LO had been taught. At this point the relevant extended learning outcome was shown and explained and students were asked to think how they could work the relevant activities into their independent study. In order to contextualise learning, and to indicate to students that extended LOs had a use in other contexts, links were made between this and previous lectures, and it was explained how the lecture fitted into the module and the module aims. The summary slide was shown after each completed section of the lecture, providing 
students with clear signals, signposting the path through the seven sections. This was done to re-capture the students' attention, prompt recall of previous information and essentially repeat the material, and to allow the students to integrate the new information with previous information.

Evaluation of the student feedback at the end of the lecture clearly showed that the students valued the structure and clarity of the session, which helped them to understand their LOs and how to achieve them. They were less enthusiastic about their understanding of how to apply this approach to future sessions, or indeed whether they would use this approach. However, this was a one-off session without any preparation of the students beforehand and perhaps indicates that such an approach should be taken earlier in their course and developed gradually over time. These students are still developing as independent learners and their response may reflect this. It would also be interesting to repeat the evaluation when students have had a chance to work with the LOs and reflect on the lecture; their responses may then be different.

We were aware of the interpersonal aspects of the process when working together to design the session. Both parties had to deal with their feelings about lack of expertise in the complementary area. This should not be underestimated as a stumbling block in an environment in which expertise confers legitimacy. It can also bring benefits if acknowledged and used. There are advantages if the learning developer is not expert in the field. First, it evens out lack of expertise, assuming that the academic does not feel themselves to be an expert in learning development. Reviewing the issue from different perspectives can be extremely stimulating as each collaborator seeks to explain their point of view in the light of the other's interests and concerns. Second, the non-expert perspective can help the expert to think about issues such as clarity, level and quality of explanation.

\section{Conclusion}

A combination of word of mouth and using available dissemination routes, such as course committees, has extended the range of teaching sessions involved to include a number of projects on several courses. Our learning development provision grows with each example. A fragmented approach, with several isolated interventions, brings benefits in its 
own right, as well as creating a climate in which a whole institution approach can be developed. Each session increases the learning development experienced by students, enabling them to explore and develop the processes through which they learn. As staff find out that they can create effective sessions without undue stress or workload their enthusiasm for the process grows and they spread the word. Our knowledge of the dynamics of the interaction between learning developer and academic also increases and we can work towards facilitating the process. The nature of the productive tensions in this relationship is one of the key messages of this case study. The other key message is that small-scale projects can have an effect on the attitudes of individuals and then on institutional attitudes. We have moved from a remedial perspective in which only failing students were perceived as needing learning development to a preventive perspective in which learning development prevents failure. We are currently developing the next attitudinal stage, in which learning development is seen as part of the process of studying a subject or discipline and is therefore part of the processes of teaching and learning. The next steps would be to develop a formal course curriculum that recognises the role of learning development as an aspect of learning about a subject or discipline and for this to become a requirement in the institutional committee and reporting structures.

\section{References}

D'andrea, V. and Gosling, D. (2001) 'Joining the dots: reconceptualizing educational development', Active learning in Higher Education 2(1) pp 64-80.

Earwaker, J. (1992) Helping and supporting students: rethinking the issues. Buckingham: Society for Research into Higher Education and Open University Press.

Lea, M.R. (2004) 'Academic literacies: a pedagogy for course design', Studies in Higher Education 29(6) pp 739-756.

Malcolm, M. (2009) 'Nurturing critical minds', Times Higher Education, 15 October 2009, p24.

Myers, J. (2007) 'Back to school: educating ourselves about students' previous learning experiences', The Science Learning and Teaching Conference. Higher Education 
Academy Centre for Bioscience, Keele University, June. ONLINE:

http://www.bioscience.heacademy.ac.uk/ftp/events/sltc07/papers/o23myers.pdf (Accessed 8 March 2010).

Myers, J. (2008) 'What do students know as they enter university?', Transition Issues for Bioscientists/Scientists Event. Higher Education Academy Centre for Bioscience, University of East Anglia, March. ONLINE:

http://www.bioscience.heacademy.ac.uk/events/norw130308.aspx (Accessed 8 March 2010).

Warren, D. (2002) 'Curriculum design in a context of widening participation in higher education', Arts and Humanities in Higher Education 1(1) pp 85-99.

Wingate, U. (2006) 'Doing away with 'study skills", Teaching in Higher Education 11(4) pp 457-469.

Wingate, U. (2007) 'A framework for transition: supporting 'learning to learn' in higher education', Higher Education Quarterly 61(3) pp 391-405.

\section{Author details}

Dr Frances Gibson is the Deputy Head of the Graduate School and Senior Lecturer in the Division of Cellular \& Molecular Medicine, St George's, University of London.

Janette Myers is the Senior Lecturer in Student Learning and Support, St George's, University of London. 